\title{
La pandemia de COVID-19 y el consultorio del primer nivel de atención
}

The COVID-19 pandemic and the first level of care office

Daniela Carrasco Zúñiga, Miguel Ángel Lezana Fernández,*

Fernando Meneses González*

Este año la salud pública mundial y sus diversos actores han enfrentado uno de los mayores retos en salud de los últimos años: la pandemia por SARS-CoV-2, o como se conoce: COVID-19. La presencia de la infección que produce este virus ha costado una enorme carga social a través de millones de enfermos y la pérdida de muchas vidas en todo el mundo. A pesar de las presiones que se ha ejercido en los sistemas de salud nacionales, y en la contención y atención de esta pandemia, se han logrado obtener muchas enseñanzas, por ejemplo, la confluencia y colaboración de los diversos grupos científicos, de profesionales de la salud y la sociedad para obtener diagnósticos rápidos, mejores esquemas de tratamiento, medidas de prevención exitosas, mejoras de la comunicación en salud hacia la población o bien el desarrollo tecnológico de vacunas en tiempos recortados.

La población, así como los profesionales de la salud, debemos tener presente que esta pandemia continuará durante algún tiempo más y, en los meses siguientes, los profesionales de la salud del primer nivel de atención serán una pieza fundamental para la contención y atención de la misma.

Por ello, la Comisión Nacional de Arbitraje Médico organizó un ciclo de conferencias virtuales titulado: «El consultorio médico y COVID-19», con el objetivo de proporcionar a los profesionales de la salud que desarrollan sus actividades en el primer nivel de atención, público o privado, información de la interacción de diversas patologías con la infección de COVID-19.

Las conferencias han sido dictadas por especialistas de alto reconocimiento profesional y académico, a quienes agradecemos profundamente su participación y el valor de la información que éstas contienen. Se publica una selección de las mismas en este Suplemento de la Revista CONAMED.

Todas las conferencias se encuentran disponibles de manera gratuita en la siguiente dirección electrónica: https://www.gob.mx/conamed, y en el canal de YouTube de la Comisión Nacional de Arbitraje Médico, los webinars correspondientes.

Esperamos que la información que contiene sea de utilidad para los profesionales de la salud del primer nivel de atención para lograr una atención oportuna, de calidad y que contribuya a reducir las consecuencias de esta infección.
* Comisión Nacional de Arbitraje Médico. Revista CONAMED.

\section{Correspondencia:}

FMG, fmenesesg@ conamed.gob.mx Conflicto de intereses: Ninguno.

Citar como: Carrasco ZD, Lezana FMÁ, Meneses GF. La pandemia de COVID-19 y el consultorio del primer nivel de atención. Rev CONAMED. 2020;

25(supl. 1): s3. https://dx.doi. org/10.35366/97342

Financiamiento: Ninguno.

Recibido: 09/12/2020.

Aceptado: 09/12/2020. 